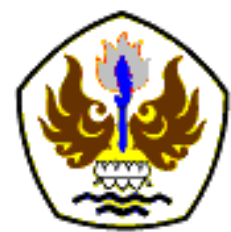

INFOMATEK

Volume 20 Nomor 1 Juni 2018

\title{
PEMODELAN REAKTOR ABSORPSI MENGGUNAKAN ABSORBEN LIMBAH LAS KARBID UNTUK MENGOLAH $\mathrm{CO}_{2}$
}

\author{
Kania Dewi $\left.{ }^{*}\right)$, Steffani \\ Program Studi Teknik Lingkungan \\ Fakultas Teknik Sipil dan Lingkungan - Institut Teknologi Bandung
}

\begin{abstract}
Abstrak: Model transfer massa dalam reaktor absorpsi semi batch untuk mengolah $\mathrm{CO}_{2}$ menggunakan limbah las karbid telah dikembangkan berdasarkan hukum kesetimbangan massa, teori transfer massa dan laju reaksi. Simulasi model reaktor dilakukan dengan solver ODE45 program MATLAB R2009a dengan pendekatan Metode Runge-Kutta orde 4. Asumsi yang digunakan dalam pemodelan ini adalah reaktor bekerja pada kondisi steady state, kedua fasa berada pada suhu $25^{\circ} \mathrm{C}$, kecepatan pengadukan serta bubbler diabaikan, dan orde reaksi merupakan pseudo orde satu. Model divalidasi dengan menggunakan hasil penelitian laboratorium absorpsi $\mathrm{CO}_{2}$ oleh limbah las karbid dalam reaktor semi batch dengan konsentrasi inlet sebesar $18 \%$. Absorpsi $\mathrm{CO}_{2}$ oleh limbah las karbid yang mengandung $\mathrm{Ca}(\mathrm{OH})_{2}$ terutama terjadi pada liquid-bulk sehingga perpindahan massa akan terjadi lebih besar di liquid-bulk dibanding dengan perpindahan massa di gas-liquid film. Model matematis yang dikembangkan dengan solusi numerik menggunakan metode Runge Kutta orde 4 secara umum dapat menggambarkan pola yang hampir sama dengan hasil penelitian laboratoirum, walaupun digunakan nilai konstanta reaksi hasil penelitian yang jauh lebih lambat daripada nilai konstanta reaksi teoritis.
\end{abstract}

Kata kunci: absorpsi, karbon dioksida, limbah las karbid, perpindahan massa, reaktor absorpsi semi batch.

\section{PENDAHULUAN}

Pemanasan global terjadi karena meningkatnya gas rumah kaca di atmosfer. Gas rumah kaca dalam konsentrasi yang berlebihan terutama karbon dioksida $\left(\mathrm{CO}_{2}\right)$, akan menyerap dan memantulkan kembali gelombang radiasi yang dipancarkan oleh bumi. Salah satu dampaknya adalah naiknya suhu global yang akan mempengaruhi iklim di bumi. Emisi $\mathrm{CO}_{2}$ salah satunya dihasilkan dari

\footnotetext{
*) kaniadewi@ftsl.itb.ac.id
}

Pertama diterima : 11 Mei 2018

Direvisi : 11 Mei 2018

Disetujui untuk publikasi: 12 Mei 2018 sumber anthropogenik terutama dari aktivitas manusia yang melakukan pembakaran bahan bakar fossil.

Penelitian terkait pengolahan $\mathrm{CO}_{2}$ untuk mengurangi emisi telah banyak dilakukan diantaranya menggunakan metode absorpsi menggunakan larutan penyerap seperti amino acid salts (Derk dan Versteeg [1], Oyenekan \& Rochele [2]), atau menggunakan larutan $\mathrm{Ca}(\mathrm{OH})_{2}$ (Yagi H., dkk., [3], Sin-Min Sih., dkk., [4]). 
Penelitian ini memanfaatkan $\left(\mathrm{Ca}(\mathrm{OH})_{2}\right)$, yang terdapat dalam dalam limbah las karbid untuk mengolah $\mathrm{CO}_{2}$ dalam suatu reaktor semi batch. Reaksi ini akan menghasilkan produk samping yakni $\mathrm{CaCO}_{3}$ (kapur) yang merupakan padatan senyawa mineral karbonat anorganik. Model matematika dikembangkan berdasarkan hukum kesetimbangan massa dan mengadopsi mass transfer film theory serta hukum Fick untuk menjelaskan konsep difusi antara gas dan cairan. Untuk membantu solusi numerik dari model yang dikembangkan, digunakan perangkat lunak komputer MATLAB R2009a.

\section{METODOLOGI}

\subsection{Reaktor Semi Batch}

Gas $\mathrm{CO}_{2}$ di dalam container bag dengan konsentrasi sebesar $18 \%$ dialirkan menggunakan pompa menuju reaktor dengan debit inlet gas $\mathrm{CO}_{2}$ sebesar 7 liter/menit. Gas $\mathrm{CO}_{2}$ kemudian diabsorpsi oleh larutan penyerap yang berasal dari limbah las karbid di dalam reaktor absorpsi semi batch. Konsentrasi gas $\mathrm{CO}_{2}$ hasil absorpsi akan diukur oleh Auto Emission Analyzer.

Rangkaian reaktor serta alur proses yang terjadi pada saat menjalankan reaktor (running) dapat dilihat melalui Gambar 1. Reaktor semi batch berbentuk silinder dengan diameter $11,5 \mathrm{~cm}$, tinggi $51,8 \mathrm{~m}$, tebal dinding
$0,04 \mathrm{~cm}$ dengan material terbuat dari flexy glass.

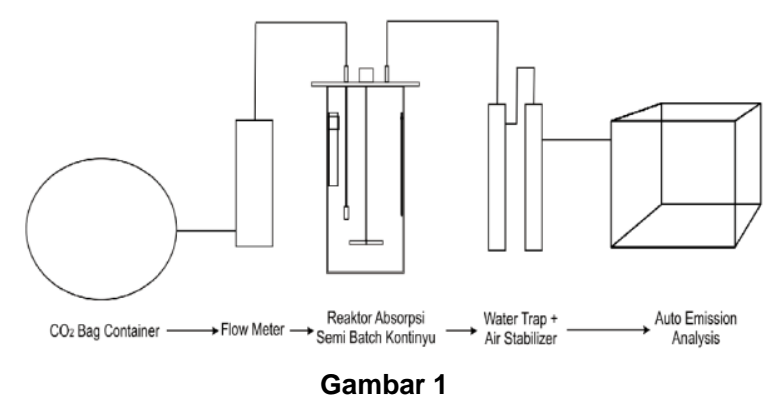

Reaktor absorpsi $\mathrm{CO}_{2}$ dalam reaktor semi batch

\subsection{Pemodelan Reaktor dan Kondisi Batas}

Kondisi batas dalam pemodelan ini dapat diuraikan sebagai berikut:

a. Kondisi kerja reaktor akan berada pada keadaan steady state (keadaan tunak) dan reaksi yang terjadi berlangsung sempurna.

b. Berdasarkan jumlah fase dan proses reaksi, reaktor merupakan reaktor heterogen, reaktan A berupa gas dan reaktan $B$ berupa cairan (liquid).

c. Kedua fase berada pada temperatur setimbang $\left(25^{\circ} \mathrm{C}\right)$.

d. Kecepatan pengadukan dan bubbler diabaikan dalam pemodelan reaktor karena merupakan faktor utama yang memiliki tujuan untuk homogenisasi sehingga larutan dan gas bercampur dengan sempurna di dalam reaktor.

e. Reaksi yang terjadi merupakan reaksi irreversible.

f. Orde reaksi merupakan orde satu semu (pseudo orde satu). 
Kondisi awal diperlihatkan pada Tabel 1.

Tabel 1

Kondisi Batas Reaktor

\begin{tabular}{|c|c|c|l|}
\hline Variabel & Nilai & Satuan & \multicolumn{1}{|c|}{ Keterangan } \\
\hline $\mathrm{C}_{\mathrm{B} 0}$ & 1,081 & $\mathrm{kmol} / \mathrm{m}^{3}$ & $\begin{array}{l}\text { Konsentrasi } \\
\text { larutan limbah las } \\
\text { karbid awal } \\
\text { berdasarkan } \\
\text { variasi massa }\end{array}$ \\
\hline $\mathrm{V}$ & 0,0038 & $\mathrm{~m}^{3}$ & $\begin{array}{l}\text { Volume larutan } \\
\text { limbah las karbid } \\
\text { dalam reaktor }\end{array}$ \\
\hline $\mathrm{X}_{\mathrm{A} 0}$ & 18 & $\%$ & $\begin{array}{l}\text { Fraksi gas CO } 2 \\
\text { awal }\end{array}$ \\
\hline$\sigma$ & 7,7 & $\mathrm{~m}^{2} / \mathrm{m}^{3}$ & $\begin{array}{l}\text { Interfacial area } \\
\text { (luas antarmuka) }\end{array}$ \\
\hline $\mathrm{Zo}$ & $9,42 \times 10^{-7}$ & $\mathrm{kmol} / \mathrm{s}$ & $\begin{array}{l}\text { Flowrate molar } \\
\text { gas total } \\
\text { (inlet) }\end{array}$ \\
\hline
\end{tabular}

\subsection{Model Matematik}

Model matematis absorpsi gas $\mathrm{CO}_{2}$ dalam reaktor semi batch dengan absorben larutan limbah las karbid, dibuat berdasarkan persamaan kesetimbangan massa secara lebih spesifik dinyatakan dalam persamaan berikut (Ingham \& Dunn [5]):

Laju Akumulasi = Laju Input Massa - Laju Output Massa + Laju Pembentukan Produk

Selanjutnya persamaan kesetimbangan massa dapat dituliskan:

$$
\frac{d C}{d t}=m o l_{\text {in }}+m o l_{\text {out }}+k C_{1} C_{2}
$$

Fenomena absorpsi berdasarkan film teori diilustrasikan pada Gambar 2. Perubahan konsentrasi gas $\mathrm{CO}_{2} \quad\left(\mathrm{C}_{\mathrm{alb}}\right)$ sebagai gas terabsorpsi serta konsentrasi limbah las karbid
$\left(\mathrm{C}_{\mathrm{Blb}}\right)$ sebagai absorbent dapat dinyatakan sebagai berikut (Wongpisan [6]):
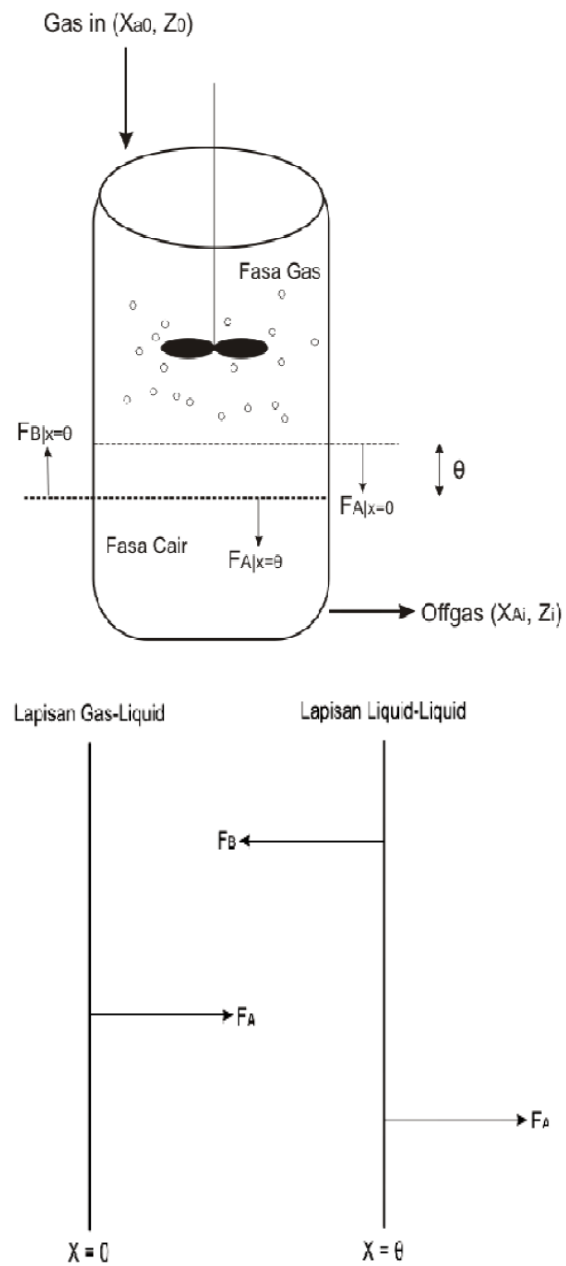

Gambar 2

Ilustrasi model film dan flux di dalam reaktor

$\frac{d C_{A l b}}{d t}=\frac{\left(F_{A l x=\theta}\right)}{V}-k C_{A l b} C_{B l b}$

$\frac{d C_{B l b}}{d t}=C_{B o}-\frac{\left(F_{A \mid x=0}-F_{A \mid x=\theta}\right)}{V}-k C_{A l b} C_{B l b}$ 
Fluks gas $\mathrm{CO}_{2}$ serta larutan limbah las karbid dapat dicari dengan pendekatan persamaan Hukum Fick:

$$
F=-D\left(\frac{d C}{d x}\right) V \sigma
$$

Fluks akan dipengaruhi oleh media kontak antara gas $\mathrm{CO}_{2}$ dengan larutan limbah las karbid sebesar volume terhadap luas antarmuka, persamaan dapat ditulis sebagai berikut (Danckwert [7]):

$$
\begin{gathered}
F_{A \mid x=0}=k_{L} V \sigma\left(X-\frac{C_{A l b}}{\operatorname{Cos} \sqrt{M}}\right) E_{A} \\
F_{A \mid x=\theta}=k_{L} V \sigma\left(\frac{X}{\operatorname{Cos} \sqrt{M}}-C_{A l b}\right) E_{A}
\end{gathered}
$$

Dengan nilai $\sqrt{ } \mathrm{M}$ terletak antara $0-\sim$, namun ketika $\sqrt{ } \mathrm{M}>>1$ semua gas yang terlarut akan bereaksi di area gas-liquid film dan tidak terjadi difusi di zona yang tidak mengalami reaksi menuju liquid-bulk. Nilai konsentrasi gas $\mathrm{CO}_{2}(\mathrm{X})$ di permukaan gas-liquid dapat dicari dengan penurunan persamaan dengan pendekatan melalui persamaan Henry sebagai berikut:

$$
(X)^{2}\left\{k_{L} V \sigma E_{A} \frac{H_{A}}{P}\right\}+X\left\{Z_{0} \frac{H_{A}}{P}-\frac{k_{L} V \sigma E_{A} C_{A b b}}{\cos \sqrt{M}}\right\}-Z_{0} x_{A 0}=0 .
$$

Persamaan-persamaan di atas dapat diselesaikan dengan data-data pelengkap seperti nilai konstanta yang diperoleh dari hasil studi literatur seperti diperlihatkan pada Tabel 2 di bawah ini.
Tabel 2

Data Penunjang Model Matematis Reaktor

\begin{tabular}{|l|l|l|l|}
\hline $\begin{array}{c}\text { Va- } \\
\text { riabel }\end{array}$ & \multicolumn{1}{c|}{ Nilai } & \multicolumn{1}{c|}{ Satuan } & \multicolumn{1}{c|}{ Sumber } \\
\hline$D_{A}$ & $2 \times 10^{-9}$ & $\mathrm{~m}^{2} / \mathrm{s}$ & Frederick \& Orville [8] \\
\hline$D_{B}$ & $2 \times 10^{-9}$ & $\mathrm{~m}^{2} / \mathrm{s}$ & {$[8]$} \\
\hline $\mathrm{H}_{\mathrm{A}}$ & $3.4 \times 10^{-3}$ & $\mathrm{kmol} / \mathrm{N} \mathrm{m}$ & Sander [9] \\
\hline $\mathrm{k}$ & $(1-10) \times 10^{-3}$ & $\mathrm{~m}^{3} / \mathrm{kmol} . \mathrm{s}$ & Rochelle [10] \\
\hline $\mathrm{kL}$ & $2,9 \times 10^{-5}$ & $\mathrm{~m} / \mathrm{s}$ & Huttenhuis et al. [11] \\
\hline Ea & $2,10,100$, & - & Brunson and Law [12] \\
& 1000 & - & {$[7]$} \\
\hline$\sqrt{M}$ & 1 & - & \\
\hline
\end{tabular}

Catatan: $\mathrm{D}=$ koefisien diffusivitas, $\mathrm{H}_{\mathrm{A}}=$ konstanta Henry, $\mathrm{k}=$ konstanta laju reaksi, Ea = enhancement factor, $\mathrm{M}=$ conversion film

Persamaan di dalam model matematika reaktor absorpsi terdiri dari dua jenis, yaitu persamaan kuadrat serta persamaan differensial. Penyelesaian persamaan kuadrat dapat dilakukan dengan pendekatan solusi secara analitik.

Untuk penyelesaian persamaan differensial digunakan pendekatan numerik metode Runge-Kutta orde 4 yang langsung dapat dilakukan oleh solver ODE45 di library program MATLAB R2009a. Fungsi diferensial ini memanfaatkan ruang dan kendali algoritma digital, MATLAB juga dapat mengintegrasikan persamaan diferensial dengan menggunakan teknik numerik yang lebih umum diantaranya metode Runge-Kutta (Burden \& Faires [13]). Algoritma penyelesaian persamaan numerik menggunakan metode Runge Kutta diperlihatkan pada Gambar 3 berikut ini. 


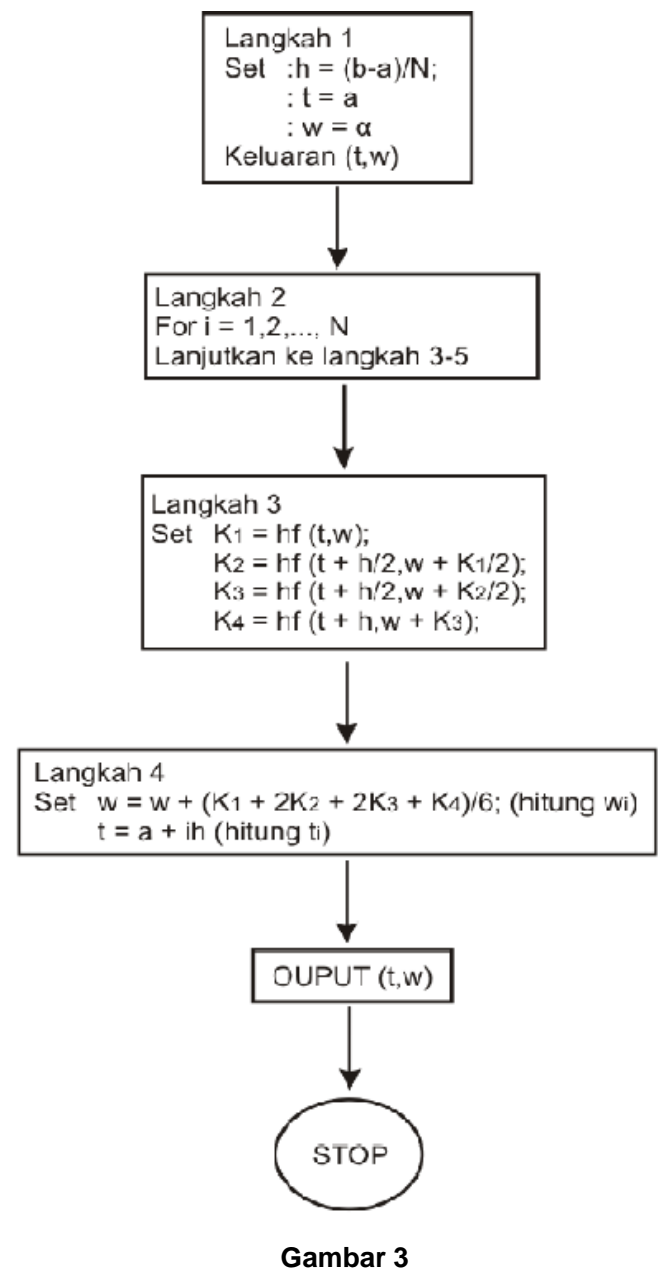

Logika algoritma metode numerik Runge-Kutta orde 4

\section{ANALISIS DAN PEMBAHASAN}

Absorpsi gas $\mathrm{CO}_{2}$ secara teoritis dalam reaktor semi batch skala laboratorium berdasarkan pemodelan dengan kondisi batas yang telah ditentukan diperlihatkan pada Gambar 4. Gambar ini menunjukkan absorpsi $\mathrm{CO}_{2}$ oleh larutan limbah las karbid dalam rentang waktu 90 menit running reaktor.
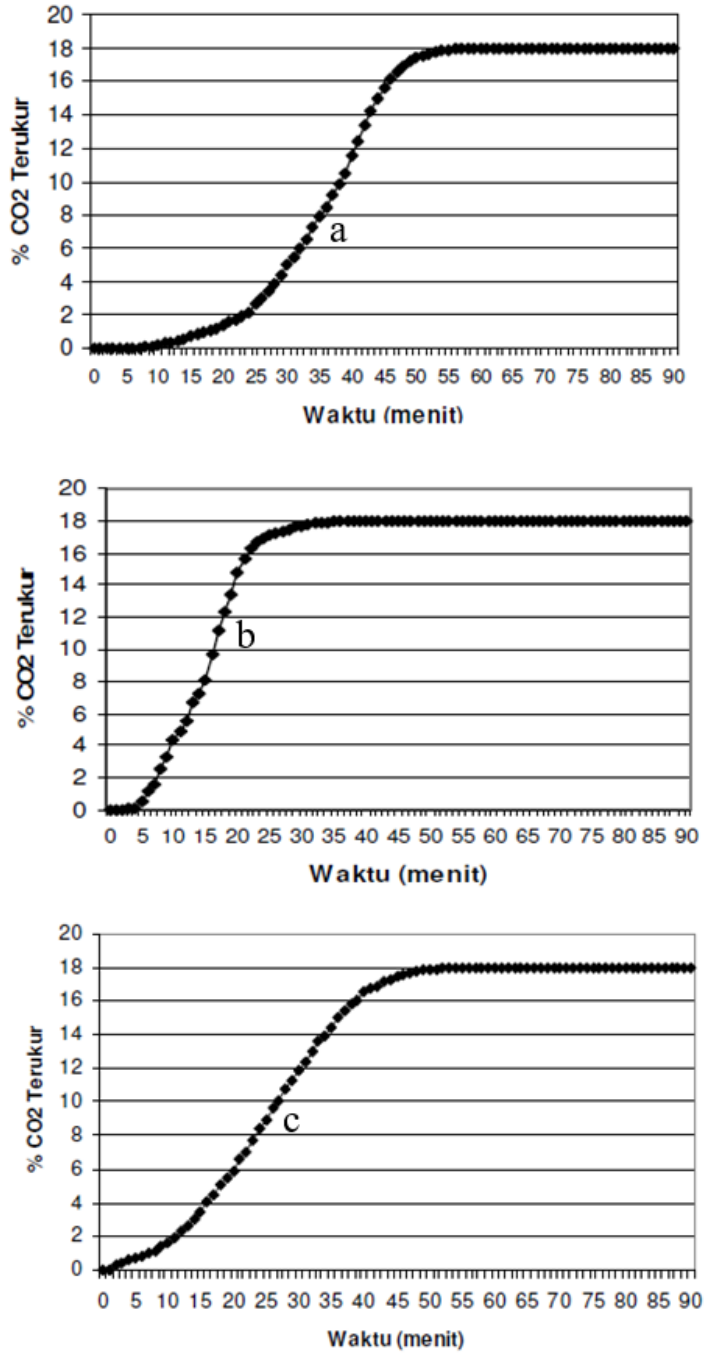

Gambar 4

(a). $\% \mathrm{CO}_{2}$ terukur pada $\mathrm{k}=0,001$, (b). $\% \mathrm{CO}_{2}$ terukur pada $\mathrm{k}=0,005$, (c). $\% \mathrm{CO}_{2}$ terukur pada $\mathrm{k}=0,01$

Fase eksponensial terjadi pada rentang waktu 0-50 menit dengan laju berbeda untuk setiap variasi variabel. Pada rentang 0-50 menit kondisi reaktor masih berada pada kondisi optimum, dan limbah las karbid masih mampu menyerap gas $\mathrm{CO}_{2}$ secara optimal. 
Persentase $\mathrm{CO}_{2}$ terukur setelah melewati semi batch reactor pada waktu setelah 50 menit mulai mendekati nilai 18\%. Hal ini berarti bahwa laju absorpsi limbah las karbid terhadap $\mathrm{CO}_{2}$ mulai menurun sehingga apabila dikaitkan dengan konsentrasi limbah las karbid, hal ini menandakan larutan limbah las karbid sudah berada pada tahap mendekati jenuh, sehingga penyerapan gas $\mathrm{CO}_{2}$ semakin menurun.

Apabila polutan gas telah mencapai batas kelarutan, maka tidak terjadi perpindahan massa pada antarmuka gas-cair. Pada kondisi ini telah dicapai kesetimbangan dimana jumlah gas yang larut dalam fasa cair sama dengan jumlah gas yang masuk dari fasa gas (US EPA [14]).

Penelitian ini merupakan penelitian terhadap absorpsi yang disertai reaksi kimia. Absorpsi yang diikuti dengan reaksi kimia dalam fase cair digunakan untuk melarutkan gas dari campuran gas. Reaksi di dalam fase cair mengakibatkan turunnya partial pressure, yang menyebabkan meningkatnya driving force yang memicu perpindahan massa.

Dalam pemodelan ini, konstanta laju reaksi merupakan variabel yang berubah. Hasil simulasi dengan menggunakan konstanta laju reaksi teoritis diperlihatkan pada Gambar 5.
Melalui gambar tersebut dapat dilihat pengaruh konstanta laju reaksi terhadap waktu absorpsi, dimana waktu absorpsi akan semakin singkat pada konstanta laju reaksi yang lebih besar. Hal ni dapat dikaitkan dengan peninjauan langkah terjadinya reaksi melalui jumlah energi kedua partikel, berasal dari energi kinetik (energi translasi) dan energi potensial (energi elektron, vibrasi, dan rotasi) nilainya konstan sepanjang terjadinya reaksi. Untuk terjadinya suatu reaksi, jumlah energi itu harus lebih besar dari energi potensial teraktivasi/Ea.

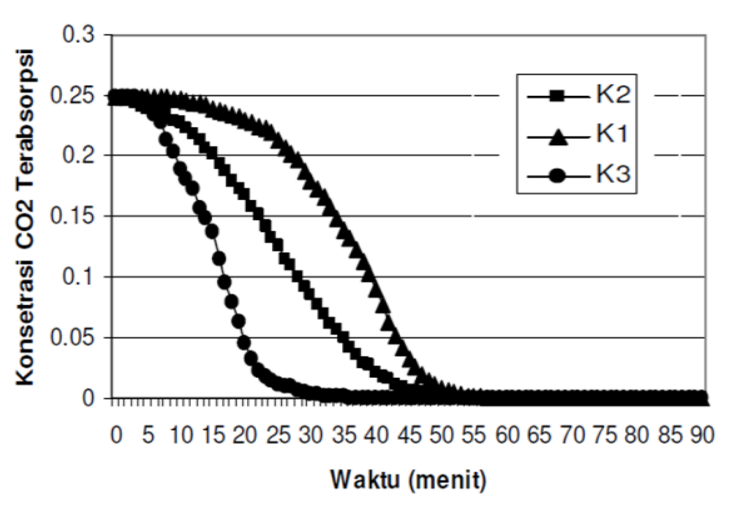

Gambar 5

Profil kosentrasi $\mathrm{CO}_{2}$ terabsorpsi berdasarkan konstanta laju reaksi teoritis

Reaksi akan terjadi apabila jumlah energi lebih besar dari energi potensial teraktivasi/Ea yang dapat dilihat melalui ilustrasi mekanisme reaksi antara $\mathrm{CO}_{2}$ dengan $\mathrm{Ca}(\mathrm{OH})_{2} \cdot \mathrm{Ca}(\mathrm{OH})_{2}$ akan terurai menjadi $\mathrm{Ca}^{2+}$ serta $\mathrm{OH}^{-}, \mathrm{CO}_{2}$ yang berkontak dengan air akan membentuk asam karbonat yang seterusnya akan terdisosiasi 
menjadi $\mathrm{CO}_{3}{ }^{2-}$ serta $\mathrm{H}^{+}$. Pada saat tahap ini, untuk dapat terjadi reaksi kedudukan kedua partikel harus sangat dekat. Karena sewaktu partikel berdekatan akan terjadi kenaikan energi potensial, energi yang terbentuk akan digunakan untuk bertumbukan.

Apabila dianalogikan terhadap konstanta laju reaksi, semakin besar konstanta laju reaksi maka kecepatan laju reaksi akan semakin besar pula. Kecepatan laju reaksi akan mempengaruhi energi kinetik yang juga meningkatkan energi potensial, sehingga tumbukan molekul akan lebih sering terjadi dan mengakibatkan peningkatan energi aktivasi yang menyebabkan terjadinya reaksi antara $\mathrm{CO}_{2}$ dengan larutan limbah las karbid $\left(\mathrm{Ca}(\mathrm{OH})_{2}\right)$ secara cepat .

Selanjutnya validasi hasil pemodelan dilakukan dengan membandingkan hasil Model dengan hasil penelitian laboratorium (Grau \& Puigjaner [15]).

Penelitian dilakukan sebanyak dua kali dengan kondisi sebagai berikut:

1. Massa limbah las karbid adalah 320 gram

2. Volume pelarut adalah 4 liter

3. Volume larutan limbah las karbid dalam reaktor adalah 3,8 liter

4. Suhu $25^{\circ} \mathrm{C}$ dan tekanan standar $1 \mathrm{~atm}$

Pada penelitian (1) dan (2) terdapat perbedaan kondisi saat running reaktor, pada running (1) larutan limbah las karbid dalam keadaan tidak jernih (hanya dekantasi), sehingga masih terdapat suspended solid (padatan $\left.\mathrm{Ca}(\mathrm{OH})_{2}\right)$. Sedangkan running ke (2), larutan limbah las karbid yang digunakan dalam keadaan jernih (dilakukan penyaringan), sehingga tidak terdapat suspended solid.

Hal ini berpengaruh terhadap kemampuan penyerapan terhadap gas $\mathrm{CO}_{2}$ oleh larutan limbah las karbid. Padatan $\mathrm{Ca}(\mathrm{OH})_{2}$ yang terdapat dalam larutan mempengaruhi absorpsi, dimana padatan akan berikatan dengan gas $\mathrm{CO}_{2}$ yang akan meningkatkan konsentrasi $\mathrm{CO}_{2}$ terabsorpsi. Melalui Gambar 6 dapat dilihat \% $\mathrm{CO}_{2}$ terukur (sisa $\mathrm{CO}_{2}$ yang tidak terserap) dengan kondisi larutan jernih (2) akan lebih besar dibandingkan larutan tidak jernih (1).

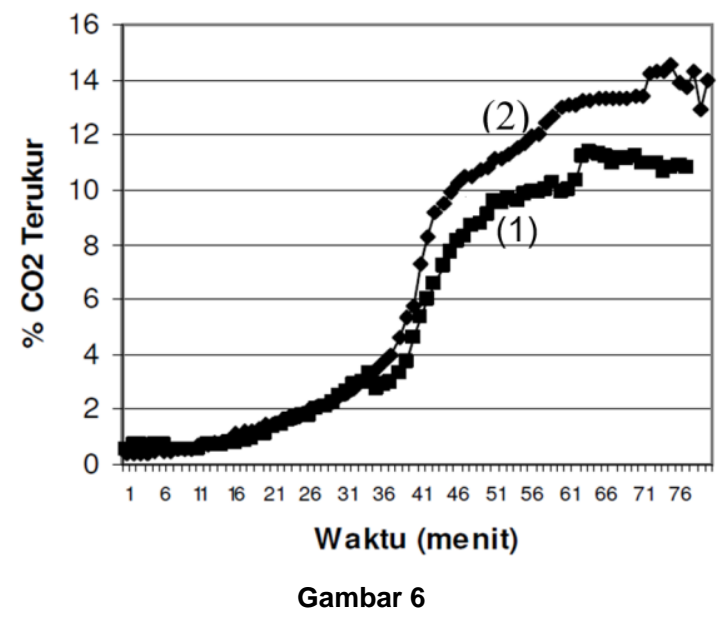

Perbandingan hasil laboratorium (1) dan hasil laboratorium (2) 
Berdasarkan hasil penelitian laboratorium terhadap absorpsi $\mathrm{CO}_{2}$ dengan absorben limbah las karbid di dalam reaktor semi batch, maka dapat diketahui konstanta laju reaksi penelitian.

Nilai konstanta laju hasil penelitian (1) sebesar $0,0000410568(1 / s)$ serta nilai konstanta laju reaksi hasil penelitian (2) sebesar 0,0000337927 (1/s). Nilai konstanta laju reaksi pemodelan yang terletak dalam rentang 0.001-0.01 jauh lebih besar dibandingkan nilai konstanta hasil penelitian laboratorium. Hasil validasi menunjukkan bahwa laju reaksi hasil penelitian laboratorium jauh lebih lambat dibandingkan dengan hasil simulasi pemodelan.

Apabila nilai konstanta hasil penelitian laboratorium digunakan untuk simulasi melalui MATLAB maka didapatkan hasil seperti pada Gambar 7 dan Gambar 8 dibawah ini.

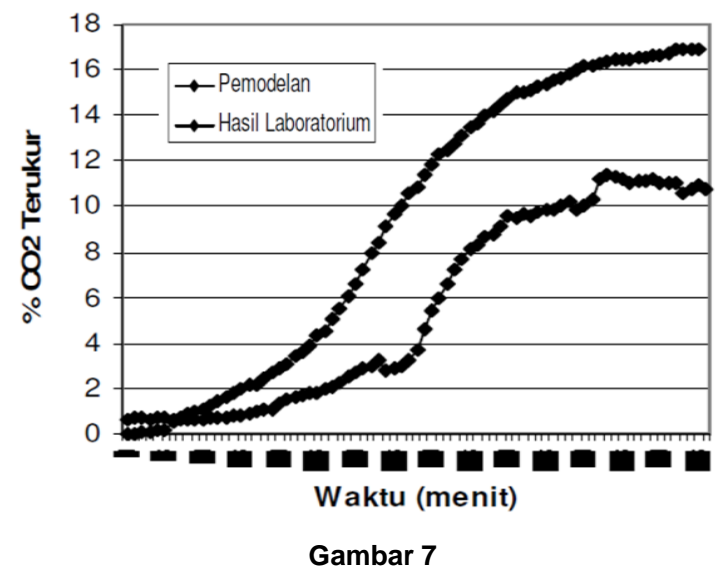

Perbandingan hasil simulasi pemodelan dengan hasil laboratorium (1)
Simulasi dengan menggunakan konstanta reaksi penelitian (1) sebesar 0,0000410568 untuk t sampai 80 menit, memberikan pola yang mendekati hasil laboratorium. Dengan menggunakan konstanta 0,0000410568 dibutuhkan waktu yang lebih singkat untuk absorpsi terhadap $\mathrm{CO}_{2}$ dibandingkan menggunakan konstanta reaksi hasil penelitian (2) sebesar 0,0000337927, dimana simulasi berjalan selama t sampai 100 menit.

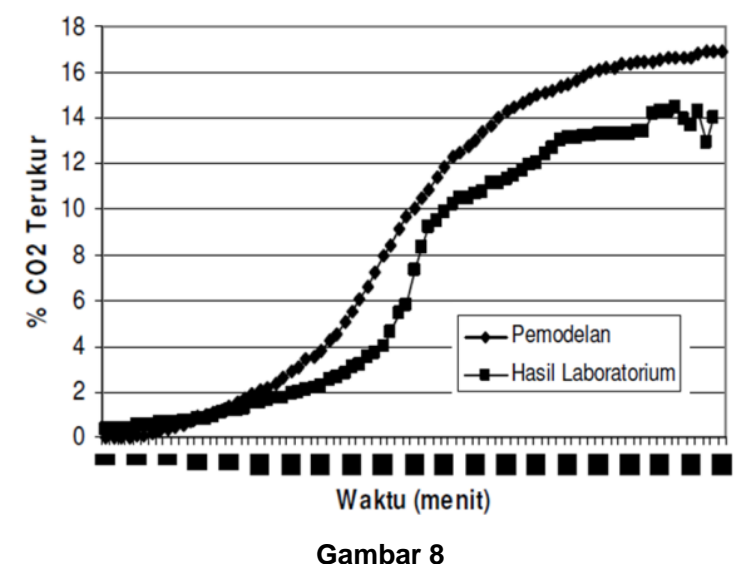

Perbandingan hasil simulasi pemodelan dengan hasil laboratorium (2)

Hasil simulasi menunjukkan bahwa model dapat mendekati pola hasil percobaan laboratorium. Dengan menggunakan konstanta 0,0000337927 dibutuhkan waktu yang lebih lama untuk absorpsi terhadap $\mathrm{CO}_{2}$.

\section{KESIMPULAN}

Model simulasi dalam penelitian ini dapat digunakan untuk memprediksi dinamika proses dan kerja reaktor semi batch. Limbah 
karbid yang mengandung $\mathrm{Ca}(\mathrm{OH})_{2}$ melalui proses karbonasi mineral dalam reaktor semi batch ini dapat dimanfaatkan sebagai alternatif untuk mengurangi emisi $\mathrm{CO}_{2}$.

Transfer massa pada gas-liquid film lebih kecil daripada dalam liquid bulk, terutama karena peristiwa penyerapan terjadi dalam liquid-bulk sehingga transfer massa akan terjadi lebih besar. Model yang dikembangkan secara umum dapat menggambarkan pola yang hampir sama dengan hasil penelitian, walaupun digunakan nilai konstanta reaksi hasil penelitian yang jauh lebih lambat dari nilai konstanta teoritis.

\section{DAFTAR PUSTAKA}

[1] Derk V.H., Versteeg G., Brilman D.W.F., dan Hogendoorn K., "Kinetic study of $\mathrm{CO}_{2}$ with various amino acid salts in aqueous solution", Chemical Engineering Science, 2009.

[2] Oyenekan B.A \& Rochele G.T., "Alternative stripper configurations for $\mathrm{CO}_{2}$ capture by aqueous amines"; American Institute of Chemical Engineering- AIChE Journal, 2007.

[3] Yagi H., Okamoto K., Naka K., Hikita $\mathrm{H}$., "Chemical Absorption of $\mathrm{CO}_{2}$ and $\mathrm{SO}_{2}$ into $\mathrm{Ca}(\mathrm{OH})_{2}$ Slurry, Chemical Engineering Communications, Volume 26 , pp. 1-9,1984.
[4] Sin-Min Shih, Ch'un-Sung Ho, YeunSheng Song, and Jyh-Ping Lin, "Kinetics of Reaction of $\mathrm{Ca}(\mathrm{OH})_{2}$ with $\mathrm{CO}_{2}$ at Low Temperature", Industrial \& Engineering Chemistry Research, pp. 1316-1322, 1999.

[5] Ingham J. dan Dunn I., "Chemical Engineering Dynamics-Modelling with PC Simulation", New York, 1994.

[6] Wongpisan, K. 2002. "Interactions of Mixing and Mass Transfer in GasLiquid Reactors". The Journal of KMITNB, Vol 14., pp 20-26, 2004.

[7] Danckwerts, P. V., "Gas-Liquid Reactions", McGraw-Hill. Inc., New York, 1970.

[8] Frederick C. TSE \& Orville C. Sandall, "Diffusion Coefficients for Oxygen and Carbon Dioxide in Water at $25^{\circ} \mathrm{C}$ by Unsteady State Desorption from $A$ Quiescent Liquid", Chemical Engineering Communications, 2007, pp. 147-153.

[9] Sander R., "Compilation of Henry's Law Constants for Inorganic and Organic Species of Potential Importance in Environmental Chemistry", Air Chemistry Department, Max-Planck Institute of Chemistry, 1999.

[10] Rochelle, Gary, " $\mathrm{CO}_{2}$ Capture by Aqueous Absorption / Stripping 
Opportunities for Better Technology". University of Texas: Department of Chemical Engineering, 2001.

[11] Huttenhuis, P.J.G. E.P. van Elk, G.F. Versteeg. 2009. "Mass transfer in a small scale post-combustion flue gas absorber, experiment and modelling". Energy Procedia 1, pp. 1131-1138, 2009.

[12] Brunson, R M Wellek, R, F. H. Law, "Enhancement Factors for Gas Absorption with Second Order Irreversible Chemical Reaction", The Canadian Journal of Chemical Engineering, Vol. 56. pp. 181-186, 1978.

[13] Burden R. and Faires J. D, "Numerical
Analysis 8th edition". Thomson Brools/Cole, USA, 2004

[14] Environmental Protection Agency, "Module 4: Liquid Characteristics - Gas Absorption", US EPA, 2010.

[15] Grau, M D dan Puigjaner L., "Batch and Semi batch Reactors Modelling and Validation Based On On-Line $\mathrm{pH}$ Measurement', Chem. Eng. Com. 2000. Vol. 17, pp. 49-65, 2000. 